\title{
ANALYSIS OF INHERITANCE DIVISION BASED ON DEEDS MADE BEFORE NOTARY PERSPECTIVE SADD AL-DZARI'AH (STUDY AT NOTARY OFFICE OF BENGKULU CITY)
}

\author{
Rizfitriani Alamsyah ${ }^{1} \&$ Toha Andiko ${ }^{2}$ \\ 1,2Pascasarjana UIN Fatmawati Sukarno Bengkulu \\ Jl. Raden Fatah Pagar Dewa Bengkulu \\ Email: ${ }^{1}$ Rizfitriani@yahoo.co.id; ${ }^{2}$ toha.andiko@gmai.com
}

\begin{abstract}
This research aims to explain: 1) How is the distribution of inheritance made by the heirs based on the deed made before the notary perspective of Sadd Al-Dzariah?, 2) What is the position of the inheritance distribution deed made before the notary perspective of Sadd Al-Dzariah?. This type of research is library research. Data collection techniques using the Document Method. The conclusion states that, 1) The heirs in dividing the inheritance do not use the Islamic inheritance system but are divided in a family manner using each party discussing each other looking for a way out of the inheritance problem being faced. 2) The implementation of the inheritance distribution in a family is not intended to avoid furudhul muqaddarah (the part set out in the text), but is nothing but for the benefit of all heirs and avoid kemudharatan. To prevent this kemudharatan, then made the Deed of Inheritance before the notary public. So in the perspective of sadd al-dzariah, the position of making the deed of distribution of legal inheritance is sunnah.
\end{abstract}

Keywords: Inheritance; Notarial Deed; Sadd al-Dzari'ah

\begin{abstract}
Abstrak: Tujuan dari penelitian ini adalah untuk menjelaskan: 1) bagaimana pembagian harta warisan yang dilakukan oleh ahli waris berdasarkan akta yang dibuat di hadapan notaris?, 2) bagaimana kedudukan akta pembagian warisan yang dibuat di hadapan notaris perspektif Sadd Al-Dzariah?. Jenis penelitian ini adalah penelitian kepustakaan. Teknik pengumpulan data menggunakan metode dokumen. Hasil kesimpulannya adalah 1) Ahli waris dalam membagi harta peninggalan tersebut tidak menggunakan sistem kewarisan Islam, tetapi dibagi secara kekeluargaan yaitu dengan cara masing-masing pihak saling bermusyawarah mencari jalan keluar dari masalah kewarisan yang dihadapi. 2) Pelaksanaan pembagian warisan secara kekeluargaan, bukan dimaksudkan untuk menghindar dari bagian yang sudah diatur jelas dalam nash, tetapi demi kemaslahatan bagi semua ahli waris dan menghindari terjadinya kemudharatan. Maka sebagai upaya antisipatif mencegah potensi munculnya kemudharatan tersebut, maka dibuatlah Akta Pembagian Waris di hadapan notaris. Sehingga dalam perspektif sadd al-dzariah, kedudukan pembuatan akta pembagian waris hukumnya sunnah.
\end{abstract}

Kata kunci: Pembagian Warisan; Akta Notaris; Sadd al-Dzariah 


\section{Introduction}

Inheritance law in Islam is a sub-system of Islamic family law (al-ahwal al-shakhsiyyah). In language, inheritance in Islamic law can be interpreted as transferring something from one person to another or from one people to another. ${ }^{1}$ While according to the term, the transfer of property rights from the deceased to the surviving heirs, whether left behind is in the form of property (money), land, or anything that is legal property rights syar'i. ${ }^{2}$

The way of sharing inheritance in Islam has been arranged in detail. The Qur'an describes in detail the laws relating to the right of inherition without neglecting the rights of any person. The division of each heir of both men and women has been determined in Surah AnNisa' (4):7. Moreover, it is also explained that the male heirs are more than the female part, namely the male heirs twice the female heirs. (Q.S. An-Nisa' (4): 11)

The above proposition clearly shows allah's command that Muslims in carrying out the division of inheritance based on the law in the Qur'an. For Muslims to carry out provisions relating to the law of inherition is an obligation that must be carried out, because it is a form of faith and piety to Allah and His Messenger. ${ }^{3}$ However, in reality, Bengkulu people divide inheritance using the principle of family and mutual agreement between heirs. Then in order to strengthen the agreement, an authentic deed was made that could protect in the days to come before the notary. Notary as a general official whom the Government authorizes to make authentic deeds and responsible for making

${ }^{1}$ Effendi Perangin, Hukum Waris, (Jakarta: Rajawali Pers, 2008), p. 3

2 Beni Ahmad Saebani, Fiqih Mawaris, (Bandung: Pustaka Setia, 2012), p. 13

${ }^{3}$ Amin Husein Nasution, Hukum Kewarisan, (Jakarta: Raja Grafindo Persada, 2012), p. 57 authentic deeds to ensure the legal certainty of the parties in carrying out an agreement. In addition, the task of notaries provides legal consulting services to the community.

The division of inheritance with the principle of family is based on the belief that the inheritance issue is the right of the individual in which the right can use or not exercise his rights or exercise his rights in a certain way as long as it does not harm the other party. The division of inheritance with the principle of family is done using deliberation, i.e. each party agrees to divide the inheritance based on the sincerity of each party when the heir (who inherited) has died, by making a deed of inheritance division before a notary.

\section{Research Method}

The type of research used is literature research related to the object of research. It means a form of research whose data source is from literature. ${ }^{4}$ In other words, this study explores the problem from the literature only, in a qualitative context it is sought to contextualize and the results of the research achieved. Because this study is a literature study, the researchers took some documents of inheritance division deeds in the notary office of Bengkulu City.

The type of approach used in this study is the Normative approach. This research will obtain an overview of the position of the deed of inheritance division made before the notary in the perspective of Sadd Adz-Dzari'ah. This research includes normative legal research, then the type of data used is secondary data. The secondary data studied are primary, secondary, and tertiary legal materials.

Based on the data obtained to compile and

4 Suryo Sukamto, Pengantar Penelitian Hukum, (Yogyakarta: UII Press, 1986), p. 13 
analyze the collected data, the method used is a descriptive analysis method, a form of analysis related to the problem studied. Descriptor analysis aims to describe the research subjects based on the data obtained."5 Thus, the researcher will explain how the position of the inheritance division deed made before the notary in perspective of Sadd Adz-Dzari'ah.

\section{Scope of Inheritance Law}

In terminology, the word inheritance comes from the word يرث ورثورث Which means waris, ${ }^{6}$ or can be interpreted as the transfer of the fulan's property from his death. ${ }^{7}$ While in the Great Dictionary of Indonesian (KBBI) the word heir means one who is entitled to receive heirlooms from people who have died. ${ }^{8}$

In terms of Muhammad Ali al-Shabuni defines Islamic inheritance as the transfer of the owner from the dead to his surviving heirs, both those he left in the form of property and rights.' Then, according to Islamic law, inheritance regulates the transfer of property left by someone who died and its consequences for his heirs. ${ }^{10}$ Moreover, various rules on the separation of property rights, the property rights in question are in the form of property, a person who has died to his heirs.

According to the usual term in Indonesia, inheritance transfers various rights and obligations to wealth from someone who died

${ }^{5}$ Sugiyono, Metode Penelitian Kuantitatif, Kualitatif Dan R\&D, (Bandung: Alfabeta, 2013), p. 148

${ }^{6}$ Ahmad Warson Munawwir, Kamus Al Munawwir, (Surabaya: PT. Pustaka Progressif, 1997), p. 1634

${ }^{7}$ Mahmud Yunus, Kamus Arab Indonesia, (Jakarta: PT. Hida Karya Agung, 1989), p. 476

8 Tim Penyusun Kamus Pusat Bahasa, Kamus Besar Bahasa Indonesia, (Jakarta: Balai Pustaka, 2001), p. 1386.

9 Muhammad Ali As-Syabuni, Al-Mawaris FiasySyariah Al-Islamiyyah, (Beirut: Dar Al-Qalam, 1409 H/1989 M), p. 32

${ }^{10}$ Effendi Perangin, Hukum Waris, (Jakarta: Rajawali Pers, 2008), p. 3 to another living person. ${ }^{11}$ Meanwhile, in the books of jurispruding, inheritance is often referred to by the term fara'id (فرايضض), mufrad Which means provisions. While fara'id in mawaris terms, the meaning is devoted to a part of the heirs determined small. ${ }^{12}$

From some of the above definitions, the author concludes that Islamic inheritance law is a law that regulates the transfer of property rights from the deceased to his heirs who are still alive, whether left in the form of property (money), land, or anything that is legal property rights sharia. The legal basis of Islamic inherition is stated in QS. An-Nisa' (4): $7-8,11,12,13,14,176$. It is in hadith, among them:

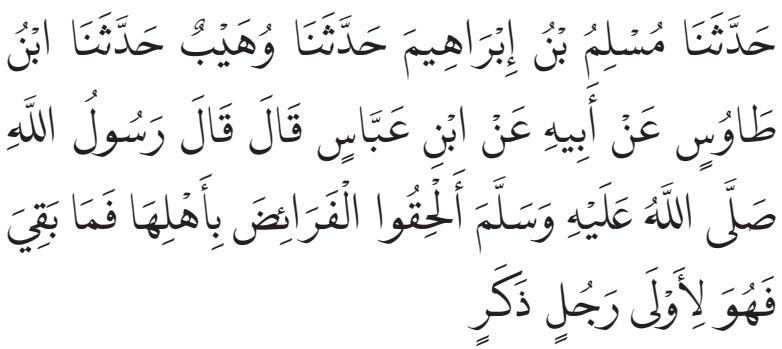

"Having told us Muslim bin Ibrahim has told us Wuhaib has told us Ibn Thawus from his father from Ibn 'Abbas said, The Prophet Shallallahu'alaihiwasallam said: Give the fara'idh (inheritance that has been established) to the rightful, then the remaining part for the heir of the closest man (nasab)." (HR. Bukhari No. 6238)

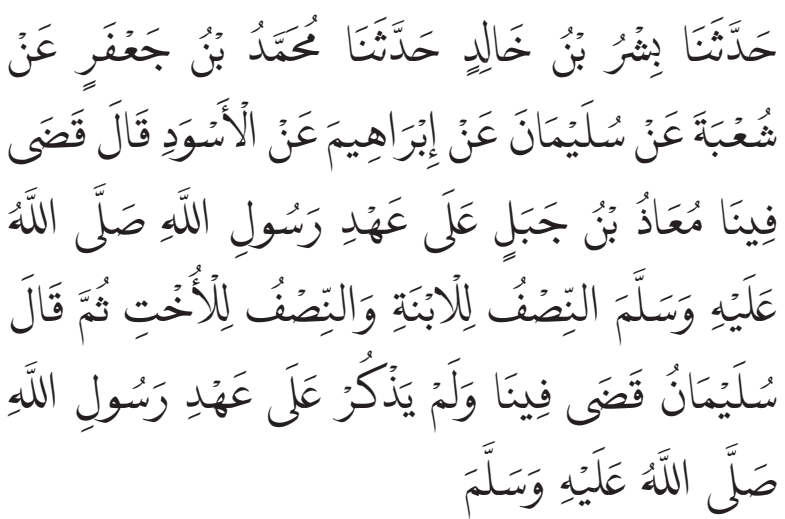

${ }^{11}$ Muslih Maruzi, Pokok-Pokok Ilmu Waris, (Semarang: Pustaka Amani, 1981), p. 1

${ }^{12}$ Fatchur Rahman, Imu Waris, (Bandung: Al-Maarif, 1981), p. 32 
"Bisyr bin Khalid has told us Muhammad bin Ja'far of Shu'bah from Sulaiman of Ibrahim of Al Aswad said; 'Mu'adz bin Jabal decided for us in the time of the Prophet Shallallahu'alaihiwasallam for girls to get half, sisters to have half, then Sulaiman said; He decided in our midst without mentioning in the time of the Prophet Shallallahu'alaihiwasallam." (HR. Bukhari No. 6244)

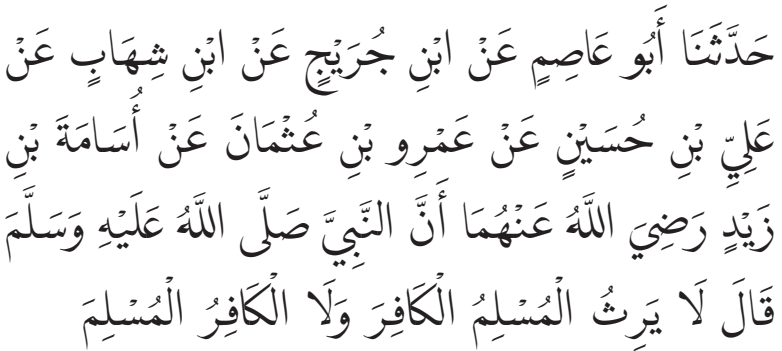

"It has told us Abu 'Ashim of Ibn Juraij of Ibn Shihab of Ali bin Husayn from Amru bin Uthman of Osama bin Zaid radliallahu 'anhuma, Prophet Shallallahu'alaihiwasallam said: Muslims do not inherit infidels, and Infidels do not inherit Muslims..” (HR. Bukhari No. 6267)

\section{Principles of Islamic Inherition}

\section{1. ljbari Principle}

Ijbari principle in Islamic law, the transfer of property from the deceased to the living applies by itself without the effort of the deceased or the will that will receive. ${ }^{13}$ The principle of ijbari in Islamic inherition law means that the transfer of the property of a deceased person to an heir takes place by itself according to the will of Allah without depending on the will of the heir or the request of his heir. The element of coercion by the meaning of the terminology is seen in terms that the heir is forced to accept the reality of the transfer of property to himself following the predetermined.

The existence of an element of ijbari in the Islamic inherition system will not burden

\footnotetext{
${ }^{13}$ Amir Syarifuddin, Hukum Kewarisan Islam, (Jakarta: Kencana, 2004), p. 16
}

the person who will receive the inheritance, because according to the provisions of Islamic law the heirs are only entitled to receive the abandoned property and are not obliged to shoulder the debt left by the heir. He simply should help pay the heir's debt with the property he left behind and is not obliged to pay off the debt with his property. ${ }^{14}$

Ijbari in terms of heir means that before he died he could not resist the transfer of the property. Whatever the heir's will to his property, his will is limited by the provisions set by God. Therefore, before he died he did not need to think or plan anything about his property; because with his death it automatically turned to his heirs, whether the heir liked it or not. The principle of ijbari in Islamic inheritance law can be seen in several aspects, namely in terms of property transition, in terms of the amount of property that is switched, in terms of who the property is switching.

The element of ijbari in terms of transition means that the wealth of the dead is transferred by itself, not transferred by anyone but God. Therefore, inheritance in Islam is interpreted as "transfer of property", not "transfer of property", because transition means switching by itself, while 'diversion' appears to be one's effort. The principle of ijbari in this transition can be seen in the word of God in the Surah An-Nisa' (4): 7 :

"For men there is a right of a share of the inheritance of parents and relatives, and for women there is a right of part (also) of the inheritance of parents and relatives, either little or much according to the section that has been set."

The form of ijbari in terms of number means that the part or right of the heir in the inheritance is determined by God, so that

${ }^{14}$ Amir Syarifuddin, Hukum Kewarisan..., p. 18 
the heir or heir have no right to increase or decrease what has been determined.

The element ijbari in terms of that number can be seen from the word "mafrudan" which etymologically means it has been determined or has been taken into account. These words in fiqh terminology mean something that God has obligated upon his servant. Combining the two possible meanings means: "the number has been determined and must be done in such a binding and coercive manner". ${ }^{15}$

\section{Bilateral Principle}

The bilateral principle of manganese means that inherited property is shifted to or through two directions. This means that everyone receives the right of inherition from both sides of the line of relatives, namely the relatives of male lineages and the relatives of female lineages. ${ }^{16}$ This liberal principle can be seen in Surah An-Nisa' verses: 11, 12 and 176. In verse 7 it is also explained that a man is entitled to inheritance from his father and mother's side. A woman is entitled to an inheritance from her father and her mother's side. This verse is the basis of the bilateral beananing.

\section{Individual Principle}

Islamic law teaches the principle of individual inheritance, with the sense that inherited property can be divided to be owned individually. Each heir receives his or her share, without being tied to the other heir. The entire estate is expressed in a particular value that may be divided, then the amount is distributed to each heir who is entitled according to the level of their respective parts.

Each heir is entitled to the share he gets without depending and being bound to

\footnotetext{
${ }^{15}$ Amir Syarifuddin, Hukum Kewarisan..., p. 20

${ }^{16}$ Amir Syarifuddin, Hukum Kewarisan..., p. 20
}

another heir. This is based on the provision that every person can accept rights and carry out obligations. In this sense every heir has the right to claim the inheritance himself and has the right not to do so.

The individual nature of the inheritance can be seen from the rules of the Qur'an that concern the division of inheritance itself. Verse 7 of Surah An-Nisa' broadly explains that both men and women are entitled to inheritance from their parents and relatives, regardless of the amount of the property, with a predetermined portion. ${ }^{17}$

From verse 7 it can be concluded that the part of each heir is not determined by the amount or most diminutive of the property left behind. On the contrary, the amount of the property is subject to the applicable provisions.

Verses 11, 12 and 176 of Surah An-Nisa' describe in detail the rights of each heir individually according to a particular and definite passage. In an insanmountable form such as a boy with a girl in Surah An-Nisa' verse 11 or a brother and sister in verse 176 , it is also explained that the balance of the division is that the male part is the same as the two parts of the female. From the balance stated it will also be clear the part of each heir.

This individual division is a binding provision and must be carried out by every Muslim with severe punishment of the hereafter for violating it, as Allah declares in Surah An-Nisa' (4): 13-14:

"(The laws) are the provisions of Allah. Whoever obeys Allah and His Messenger, Allah will put him in heaven that flows in the rivers, while they remain in them; And that is a great victory and whoever disobeys Allah and His Messenger and violates His provisions, Allah will put him in the fire of

\footnotetext{
${ }^{17}$ Amir Syarifuddin, Hukum Kewarisan..., p. 21
} 
hell while he remains in it; And for him an insulting punishment."

\section{Balanced Justice Principle}

It can be said that gender differences do not determine the right of inherited in Islam. That is, like men, women get equally strong rights to inheritance. This is mentioned in the Qur'ansurah An-Nisa' verse 7 which equalizes men and women's right to inheritance. ${ }^{18}$ In verses 11,12 and 176 surah An-Nisa' in detail described the equality of the power of inheritance rights between sons and sisters, father and mother (verse 11), husband and wife (verse 12), brothers and sisters (verses 12 and 176).

In terms of the number of parts gained when receiving rights, there is indeed inequality. However, that does not mean unfair, because justice in the Islamic view is measured by the amount obtained when receiving inheritance rights and attributed to usefulness and need. ${ }^{19}$

In general, it can be said that men need more material than women. This is because men in Islamic teachings bear a double duty that is for himself and to his family including women, as explained in the word of Allah:

"The men were leaders to women, because Allah had overestimated some of them over others, and because they had provided for some of their wealth. Therefore, a righteous woman is self-righteous when her husband is not there because Allah has kept (them). The women you are worried about, so advise them, separate them in their beds, and beat them. Then if they obey you, do not look for ways to trouble them. Surely God is great." An-Nisa' (4): 34

When connected with the amount received with obligations and responsibilities as

\footnotetext{
${ }_{18}$ Amir Syarifuddin, Hukum Kewarisan..., p. 22

${ }^{19}$ Amir Syarifuddin, Hukum Kewarisan..., p. 23
}

mentioned above, it will be seen that the level of benefits that men will feel is the same as what is felt by women. Although men initially receive twice as much as women, some of what is accepted will be given to women in their capacity as responsible leaders. This is justice in the Islamic concept.

\section{The Only Basis of Death}

Islamic law stipulates that the transfer of one's property to another using the term inheritance only applies after the one who owns the property has died. This principle means that one's property cannot be transferred to another person by inheritance name as long as the one who has the property is still alive. It also means that any transfer of a person's surviving property either directly or directly after he dies, is not included in the terms of inheritance according to Islamic law. Thus the law of Islamic inherition only recognizes one form of inherition, namely the inherition due to death alone. ${ }^{20}$

Furthermore, the process of transitioning property from the dead to the living in Islamic inheriting law knows three elements: heirs, inheritance, and heirs.

The heir, who in fiqh literature is called al-muwarrits, has died and left something that can turn to his surviving family. Based on the principle that the transfer of property from heir to heir takes effect after the heir's death, the word "heir" is appropriate for understanding a dead person. Based on the principle of ijbari, the heir before his death has no right to determine who will get the property he left behind, because God has determined everything. His independence to act on the property was limited to the sum of one-third of his property. ${ }^{21}$

\footnotetext{
${ }^{20}$ Amir Syarifuddin, Hukum Kewarisan..., p. 25

${ }^{21}$ Amir Syarifuddin, Hukum Kewarisan..., p. 203
} 
The restriction of acting against a person in the event of the use of his property in the lead-up to his death is to safeguard the rights of the heirs. The right of the heir to determine who will receive his property is not to violate the personal rights of the heirs according to what has been established by God.

It has been explained in the Qur'an, that the heir is a parent, a relative and one of the husband or wife. This is generally explained in Surah An-Nisa' verse 7 about parents and relatives, confirmed by verse 33 by adding a husband or wife. Word of God:

"For men there is a right of a share of the inheritance of parents and relatives, and for women there is a right of part (pula) of the inheritance of parents and relatives, either little or much according to the section that has been established."(Q.S. An-Nisa'(4): 7)

The condition that must be fulfilled about this heir is "the clear death". This fulfills the principle of inheritance due to death, which means that the heir's estate is transferred to his heirs after his death. If a person is not clear of his death and there is no news of his life or death, then his property remains his whole as in the apparent circumstances of his life.

While the inheritance according to Islamic law is everything left behind by the heir who can legally turn to his heirs. In this meaning can be distinguished between inheritance and relics. Relics are all left behind by the mayit or in any sense what is in the relic at the time of his death, while the inheritance is a relic that is legally syara' entitled to be received by his heirs. ${ }^{22}$

When it is considered the Qur'anic verses that establish the law of inheritance, it appears that the inheritance of Allah uses the word "nothing left behind" by the deceased. Words

${ }^{22}$ Muhammad Ali As-Shabuni, Hukum Kewarisan Menurut Al-Qur'an Dan Sunnah (Jakarta: CV. Diponegoro, 2004), p. 64 like these are found 11 times mentioned in inherited relations, namely twice in Surah AnNisa' verse 7 , twice in verse 11 , four times in verse 12, once in verse 33 and twice in verse 176.

Every word "abandoned" in the above verses is preceded by the word "nothing". In Arabic the word "nothing" contains a general meaning. ${ }^{23}$ The generality is more clearly mentioned in verse 7 of Surah An-Nisa' whose translation is: "... It is good that what is left is little or a lot..."

That not the whole of the heir's "left behind" becomes heirs can be understood from the relation of the division of inheritance to some of the actions that preceded it, which in the verse stated two things, namely paying the will he issued and paying all debts made before he died, as mentioned by Allah in verse 11 and verse 12 of Surah An-Nisa'.

When it is noted that the debt of the heir is the right of the person who owes and the will has legally become a right for the person given the will, while both are prerequisites for the distribution of inheritance. So the first action against the heir's inheritance purifies or frees him from his connection to the rights of others in it.

From the description above it can be concluded that inheritance is what is left behind by the heir, despite all kinds of rights of others in it. The understanding of inheritance in such a formulation occurs among Hanafi scholars. ${ }^{24}$

Other Fiqh scholars put forward a different formula from the one formulated above. For them the inheritance is all that he left at the time of his death, whether in the form of property or rights. ${ }^{25}$

${ }^{23}$ Muhammad Ali As-Shabuni, Hukum Kewarisan..., p. 64

24 Suhrawardi K. Lubis dan Komis Simanjuntak, Hukum Waris Islam, (Jakarta: Sinar Grafika, 2008), p. 39

25 Suhrawardi K. Lubis dan Komis Simanjuntak, Hukum Waris..., p. 39 
When considering the formulation put forward by scholars other than Hanafi as mentioned above, it can be understood that there is no difference between inheritance and relics according to them. However, if noticed in the subsequent implementation, before the relic is distributed to the heirs, he must first be issued his will and debt, as demanded by Allah Swt. in verses 11 and 12 of Surah AnNisa'. Thus, it is clear that the two groups of scholars differ only in formulation, while the substance is the same.

In the above discussion it has been stated that the property that becomes the property of the inheritance must be purely from the rights of others in it. Among the efforts to purify the rights of others is to issue a will and pay the debt of the owner of the property. The law concerning the payment of debts and wills can be developed into other things and events to the extent in which there are rights of others which must be purified from late's inheritance. ${ }^{26}$ The cost of holding the body to the buried included the medical expenses of sick time that led to his death.

As for heirs, Islamic law recognizes three groups: ${ }^{27}$

a) Heirs who acquire certain parts according to the Qur'an and Hadith, are called dzawil furudh. Which includes the heirs of dzawil furudh consists of 12 people, namely: husband, wife, father, mother, daughter, granddaughter (of a son), sister sekandung, sister, sister and sister seibu, grandmother and grandfather.

b) The heirs whose parts are not specified in the Qur'an, al-Hadith, are called heirs of ashabah.

c) Heirs who have a kinship with the heir,

\footnotetext{
26 Ahmad Rofiq, Figh Mawaris, (Jakarta Utara: PT.Raja Grafindo Persada, 2005), p. 4

${ }^{27}$ Ahmad Rofiq, Fiqh Mawaris..., p. 4
}

but do not belong to the previous heirs, are called dzawil arham.

While the causes of the inherition of Islam are:

1. Al-Qarabah (kinship) or also called nasab (blood) relationship, which is every fraternal relationship caused by birth (offspring), both near and far. Qarabah (Fiqh term) is a relative, relative. There is Qarabah ba'idah (distant relative) and there is Qarabah Qaribah (close relative). ${ }^{28}$

Blood relationships are causing inherited inheritance. This nasab relationship includes the offspring of corpses (furu al mayt) and ancestors and offspring (furu ushuli). ${ }^{29}$ They will get an inheritance with the fardh part only like the mother, or fardh with ashabah like the father's part or ashabah only like a brother or by the cause of rahm (dzawil arham) like uncle from mother. ${ }^{30}$ God says in QS.Al-Anfal (8):75:

"And those who believe after that then migrate and fight with you, and those are among you. Those who have relative relationships are more entitled to others (than non-relatives) in the book of God. God knows everything."

Thus, this relationship includes father and mother, children, brothers, uncles (fathers brothers) and anyone who has a relationship with them. ${ }^{31}$

2. Marriage relationship. The marriage relationship here is an inherited relationship caused by a valid marriage contract. Because of the contract, the husband inherits the

\footnotetext{
${ }^{28}$ M. Abdul Mujieb, Kamus Istilah Fikih, (Jakarta: PT. Pustaka Firdaus, 1994), p. 271

29 A Assaad Yunus, Pokok-Pokok Hukum Kewarisan Islam (Faraidh), (Jakarta: PT. Al- Qushwa, 1992) p. 25

${ }^{30}$ Mohammad Athoillah, Fikih Mawaris, (Bandung: Yrama Widya, 2013), p. 20

${ }^{31}$ Mohammad Athoillah, Fikih Mawaris..., p. 21
} 
wife's property and the wife inherits the property of the husband, although he has never had intercourse and sex (staying alone). This is based on The Word of God. QS. An-Nisa' (4): 12.

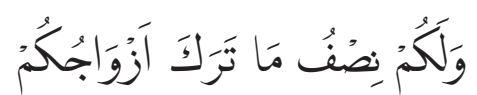

"And for you (husbands) two-second of the property left behind by your wives,...

The fukaha agreed that the divorced wife of the husband who in the time of Iddah raj'iyah can inherit (receive the inheritance of her husband's inheritance). As for the wife who is in Thalak ba' in by the husband who is in good health does not inherit the husband's property even though (the husband died) in the iddah period.

Nevertheless, if the wife is in talaq when the husband is seriously ill (because he avoids giving inheritance to the wife), the scholars differ opinions. Hanafiyah scholars argue that the wife inherits the husband's property when when the husband dies, his iddah has not been exhausted; Even according to Malikiyah scholars the wife inherits the husband's property even though it has expired and is married to another man, while according to the ulama Hambali the wife can inherit it even though it has run out of iddah, as long as it has not married another man based on abi Salmah's view r.a. that Abdurrahman bin Auf divorced his wife (talaq three) when he was sick, then Usman bin Affan gave Abdurrahman's inheritance to his wife after the end of his iddah period. While shafi'iyah scholars do not allow giving inheritance to wives in talaq ba'in even though iddah has not been exhausted, because al-baynunah (talaq ba'in) severes the relationship of the husband and wife who are the cause of receiving inheritance. ${ }^{32}$

${ }^{32}$ Mohammad Athoillah, Fikih Mawaris..., p. 21
As for the fasid marriage that has been agreed such as marriage without witnesses, marriage is void such as mut'ah marriage does not include syar marriage then the marriage is not a cause of mutual inherition; While the façade marriage that mukhtalaf (not agreed) like marriage without a guardian, then according to some scholars may inherit each other between husband and wife because of syubhat al khilaf and according to other scholars do not inherit each other because the marriage is a façade (legal defect). ${ }^{33}$

3. Family inheriting (Takharuj). In the sense of the word, takharuj means out to each other. ${ }^{34}$ In the usual terminology sense it means the exit of a person or more than a collection of heirs to replace his rights from one among the other heirs. ${ }^{35}$

In the division of inheritance, the part of each heir in a particular case does not correspond to the urgent needs or individual desires of the heir so that in certain circumstances, the implementation of the law according to what is looks inappropriate and less perceived reasonably. For example, an heir is a widow who has nothing but the relics of her late husband and a brother of her husband's brother. Under the law, the widow only gets $1 / 4$ (quarter) and the brother gets the rest 3/4 (three quarters). Legally the brother has no obligation whatsoever to finance the needs of the widow. Under certain circumstances relics may take the form of houses, land and money. Among the heirs some only need a house, others need land and others need

${ }^{33}$ Mohammad Athoillah, Fikih Mawaris..., p. 21

${ }_{34}$ Muhammad Ali as-Shabuni, Hukum Waris, terj. Abdul Hamid Zahwan, (Solo: CV. Pustaka Mantik, 1994), p. 135.

${ }^{35}$ Amir Syarifuddin, Hukum Kewarisan Islam, cet. Ke 2. (Jakarta: Kencana, 2005), p. 297 
money. In the settlement of inheritance, each one does not get what he needs.

Concerning the definite provisions in the division of inheritance and the wishes of certain parties in certain circumstances that demand other means, there is indeed no proposition that is a clue to its exclusion. Nevertheless, the demands for justice and the parties' willingness will be able to solve the problem. Settlement in this case can occur in two forms.

First: the settlement is done after the completion of the division of inheritance. This means that after the division of each is determined and each has received his rights, the entire inheritance is merged again, then divided according to mutual agreement with their respective wishes. In this way each party receives its share according to its needs, while the law has been formally carried out.

In practical implementation, inheritance is divided according to mutual willingness based on their individual needs. This can only be achieved if an agreement can be reached and each party does not feel aggrieved. Agreements in the face of property division often cannot be reached, which often applies to disputes that outsiders must resolve.

Second, the settlement takes place before the division of inheritance. This means the agreement of all heirs to pursue the way of sharing inheritance outside the way specified by the syara'. In a particular sense the agreement of all heirs for the exit of a person or more than the heirs of the division of inheritance in exchange for those taken from the group of inherited property. It can also mean that by mutual agreement, one of the heirs relinquishs his rights from the division of inheritance by taking one form of inheritance. This way in islamic legal literature is called takharuj or tasaluh. ${ }^{36}$

\section{Sadd al-Dzari'ah Concept}

Dzari'ah الذريعة means "a way to something”. 37 means to close or to stop and الذريعة means or a way to achieve the goal. ${ }^{38}$ Sadd adzdzari'ah means "inhibiting or clogging that becomes an intermediary".

In terms according to Abdul Karim Zaidan, namely closing the road that leads to destruction or evil. ${ }^{39}$ According to Asmawi, sadd al-dzari'ah is generally interpreted as a mujtahid attempt to establish a ban on one legal case that is a disaster. The ban is intended to avoid other prohibited acts or acts. This method is preventive. All that is evil but will lead to an haram deed, the law becomes haram. ${ }^{40}$

According to Asmawi, sadd al-dzari'ah is generally interpreted as a mujtahid attempt to establish a ban on one legal case that is a disaster. The ban is intended to avoid other prohibited acts or acts. This method is preventive. All that is evil but will lead to an haram deed, the law becomes haram. ${ }^{41}$ According to Asmawi, sadd al-dzari'ah is generally interpreted as a mujtahid attempt to establish a ban on one legal case that is a disaster. The ban is intended to avoid other prohibited acts or acts. This method is preventive. All that is evil but will lead to an

\footnotetext{
${ }^{36}$ Muhammad Ali as-Shabuni, Hukum Waris..., p.135.

37 Abu Rokhmad, Ushul Al- Figh, (Semarang: CV. Karya Abadi, 2015), p. 248

38 Basiq Djalil, Ilmu Ushul Fiqh, (Jakarta: Kencana Group, 2014), p. 169

39 Satria Effendi, Ushul Figh, (Jakarta: Prenada Media Group, 2008), p. 172

${ }^{40}$ Asmawi, Perbandingan Ushul Fiqh, (Jakarta: Amzah, 2011), p. 142

${ }^{41}$ Djazuli, Ilmu Figh, (Jakarta: Kencana Media Group, 2005), p. 98
} 
haram deed, the law becomes haram. ${ }^{42}$

From the description above it can be concluded that sadd adz-dzari'ah is to prevent an act that is forbidden to not cause damage (mafsadah). The use of mafsadah is done because it is forbidden. The purpose of sadd adz-dzari'ah is to create good and avoid damage (mafsadah).

As is the case with qiyas, the position of Sadd Adz-Dzari'ah is seen from the aspect of its application, sadd adz-dzari' ah is one of the methods of legal decision-making (istinbath al-hukm) in Islam. However, in terms of legal products, sadd adz-dzari'ah is one of the sources of the law.

Not all scholars agree with sadd adzdzari'ah as a method of establishing the law. In general, the various views of these scholars can be classified into three groups. The first group, which accepts fully to establish the law, is the Maliki school and the Hambali school. ${ }^{43}$ The second group, which does not accept fully as a method of establishing the law, is the Hanafi school and the Shafi'i school. An example of imam Shafi'i using sadd adz-dzari' ah, is when he forbids someone to prevent water flow to plantations or rice fields. This according to him will be a means (dzari'ah) to prevent the obtaining of something that is hindered by Allah and dzariah to the act of forbidding something that Allah prohibits. ${ }^{44}$

An example of the use of sadd adz-dzari'ah by the Hanafi school is about a woman who is still in iddah because of the death of her husband. The woman is forbidden to be ornate, using fragrances, eye repellent, boyfriends, and striking clothes. With an ornate (ihdad),

${ }^{42}$ Mukhtar Yahya dan Fatchurrahman, Dasar-dasar Pembinaan Hukum Islam: Figh Islami, (Bandung: PT. AlMa'arif, 1986), p. 347

${ }^{43}$ Abu Rokhmad, Ushul Al-Figh..., p. 250

${ }^{44}$ Basiq Djalil, Ilmu Ushul..., p. 175 the woman will attract men. Nevertheless, he is not in a state of marriage. Therefore, the prohibition is sadd adz-dzari'ah so that no forbidden deeds occur, namely the marriage of women in a state of iddah. ${ }^{45}$

Dzari'ah when viewed from the consequences (impact) caused according to Ibn al-Qoyyim, as quoted by Amir Syarifuddin is divided into four types, namely: ${ }^{46}$

a. Dzari'ah does lead to damage such as drinking liquor that leads to the destruction of reason, or adultery that will lead to the destruction of offspring.

b. Dzari'ah was initially been for something calamitous, but ended up leading to destructive evil deeds, such as muhalil marriage or berating the worship of other religions. Marriage is permissible, but because the purpose is merely to justify the haram, it becomes forbidden.

c. Dzariah is back for something calamity. Like decorating for a woman who undergoes iddah left behind her husband. The ornate is permissible, but the ornate woman iddah, like that the situation becomes other.

d. The Dzariah was initially been for something terrible, but the bad was less than his good. For example, like looking at a woman's face when looking at a khitbah.

Dzari'ah when viewed from the level of damage caused, Abu Ishaq al-Syathibi, as quoted by Ma'ruf Amin divides it into four types, namely: ${ }^{47}$

a. It was the Dzari' ah that brought the damage with certainty. For example, digging a hole in the ground itself near the door of

\footnotetext{
${ }^{45}$ Satria Effendi, Ushul Figh..., p. 172

46 Amir Syarifuddin, Ushul Figh Jilid II, (Jakarta: Logos Wacana Ilmu, 1997), p. 402

${ }_{47}$ Ma'ruf Amin, Fatwa Dalam Sistem Hukum Islam, (Jakarta: Elsas, 2008 ), p. 198
} 
someone's house in the dark, everyone who comes out of the door must fall into the hole. Digging the hole is fine, but such excavation will cause danger / damage.

b. Dzari'ah leads to damage according to usual, meaning that if the dzari'ah is done, then most likely there will be damage or will be done deeds that are prohibited. For example selling wine to liquor producers, or selling sharp weapons to criminals.

c. Dzari'ah which leads to forbidden deeds, this means that if the dzariah is not avoided, it will result in criminal deeds. For example, buying and selling credit (installment system), it does not always lead to riba, but in practice is often a means to the deeds of riba.

\section{Overview of Notary Departments and Notary Deeds}

Notary Department

The term Notary is derived from the word "notarius" (Latin), the name given to the Romans in which the work of writing or those who took notes at that time. ${ }^{48}$

For more than a century, the existence of notaries in office was based on the provisions of the Reglement of Het NotaryAmbt In Nederlandsch No. 1860: 3 which came into force on July 1, 1860. In that period, the Notary Department Regulations underwent several changes. At this time, the Notary has its Law with the birth of Law No. 30 of 2004 concerning the Notary Office. ${ }^{49}$

Notary in his office is an institution that gives rise to written proof tools and has authentic properties. In this case, the notary must be active in his work, and willing to

\footnotetext{
${ }^{48}$ Habib Adjie, Hukum Notariat Indonesia, (Bandung: PT Refika Aditama, 2008), p. 20

${ }^{49}$ Notodisuryo, Hukum Notariat di Indonesia (suatu penjelasan), (Jakarta: Raja Grafindo, 1993), p. 8
}

serve the community in need of the services of a notary.

Notary understanding in the Civil Law system stipulated in Article 1 Ord, stbl. 1860 number 3 on the Notary Office in Indonesia came into force on July 1, 1860 which R. Soegondo later translated mentioned that the notion of Notaries are general officials, especially (the only) who are authorized to make authentic deeds about all actions, agreements, and decisions required by general legislation to be desired by the concerned that it is stated in authentic letters, guarantee the date, keep the deeds and issue grosses, copies (derivatives) and quotations. All of that is when making such deeds or devoted to it or devoted to other officials or persons. ${ }^{50}$

For the sake of notary interests and to serve the interests of the Indonesian people, the Government on October 6, 2004 has passed Law No. 30 of 2004 on Notary Position (UUJN), and has been amended by Law Number 2 of 2014 on Amendments to Law No. 30 of 2004 on Notary Positions.

Historically, a Notary is a State official/ general official whom the State can appoint to perform the duties of the State in the service of law to the community to achieve legal certainty as an official of authentic deed making in civil matters. Notary understanding is contained in the provisions of Law No. 30 of 2004 concerning The Office of Notary Chapter I Article 1 paragraph (1), i.e. Notary is a general official who is authorized and represents general power to make authentic deeds and other authorities as referred to in this Law, for proof or as a means of evidence.

Considering the description of Article 1 of the Notary Office Act, it can be explained that the Notary is: a. general official, b. authorized

\footnotetext{
${ }^{50}$ Notodisuryo, Hukum Notariat...., p. 10
} 
to make authentic deeds, c. determined by $\mathrm{law}^{51}$. The notary's job is to construct the legal relationship between the parties in a written form and a specific format, so that it is an authentic deed. He is a substantial document maker in a legal process. $^{52}$

The duties and authority of the Notary according to Article 1 of the Notary Department Act do not provide a complete description of the duties of the Notary. According to Lumban Tobing, ${ }^{53}$ "in addition to authentic deeds, notaries are also assigned to register and approve letters or deeds made under the hands." Notaries also provide legal advice and explanations of laws and regulations to the parties concerned.

The nature of the notary's duty as a general official is to arrange in writing and authentically the legal relationship between the parties who benefit and agree to request the services of a notary which is essentially the same as the duty of the judge who provides justice among the parties to the dispute. In the construction of notary law, one of the duties of the notary position is to formulate the wishes or actions of the interceptors into the form of authentic deeds, taking into account the applicable rule of law. ${ }^{54}$

That notaries are impartial but independent and not as one party and impartial to those concerned. In carrying out his duties and positions as a general official there are provisions of the Law that are so strict for certain people, not allowed as witnesses or as interested parties on the deed made before him.

The main task of the notary is to make an authentic deed. As for the original word

${ }^{51}$ Tan Thong Kie, Studi Notariat, Serba-serbi Praktek Notaris, (Jakarta: PT. Ichtiar Baru Van Hoeve, 2000), p. 159

52 Tan Thong Kie, Studi Notariat..., p. 159

${ }^{53}$ Lumban Tobing, Peraturan Jabatan Notaris, (Jakarta: Erlangga, 1992), p. 37

${ }^{54}$ Lumban Tobing, Peraturan Jabatan..., p. 37 according to Article 1870 of the Civil Code gives to the parties who make it a perfect proof. Therein lies the significance of a notary, that the notary because the Law is authorized to create a perfect means of proof, in the sense that what is in the authentic deed is essentially considered accurate as long as there is no evidence to the contrary.

Regarding the authority that a notary must own as a general official to make an authentic deed, a notary may only exercise in the area or territory specified for him and only within that area or jurisdiction he is authorized (Article 18 UUJN). If the notary makes a deed outside his jurisdiction then the deed is invalid.

Notary authority includes 4 (four) things, namely: ${ }^{55}$

a. Notary is authorized as long as it concerns the deed he made. A general official can only make certain deeds assigned to him based on the laws and regulations, and not every general official can make all deeds. Notaries are only authorized to make authentic deeds of civil law as long as they are not the authority of other general officials and are not authorized to make authentic deeds in the field of public law.

b. Notaries are authorized as long as regarding the people for whose purposes the deed was made. Notaries are not authorized to make deeds for the benefit of every person, as stated in Article 52 of the UUJN, that notaries are not allowed to make deeds in which the notary himself, his wife, blood family or semenda of the notary in a straight line without restriction of degrees and the line of sideways up to the third degree either personally or through the power to be a party.

c. The notary shall be authorized as long as

${ }^{55}$ Lumban Tobing, Peraturan Jabatan...., p. 39 
regarding the place, where the deed was made. Following Article 19 of the UUJN, the notary is not authorized to make deeds outside the territory of his position. If it is made outside its jurisdiction, the deed is considered an under-the-hand deed.

d. Notaries must be authorized at all times of the deed. The notary may not make a deed as long as he is still on leave or is fired from his position and also he cannot make a deed as long as he is in office (before his oath).

Notary in carrying out his duties and position as a general official authorized to make authentic deeds, can be burdened with responsibility for his actions in connection with his work in making the deed. Such responsibility as an essential willingness to carry out its obligations. The scope of notary accountability includes material truth to the deeds it makes. The notary is not responsible for the negligence and error of the content of the deed made before him, but instead the Notary is only responsible for the proper form of the authentic deed as required by law. Regarding the responsibility of notaries as general officials related to material truth is divided into four points, namely:

a. The notary's civil responsibility for material truth to the deeds he made. Juridical construction used in civil liability for material truth against deeds made by notaries is the construction of unlawful acts.

b. The notary's criminal responsibility for material truth in the deed he made. Regarding criminal provisions are not regulated in UUJN but the responsibility of notaries is criminally imposed if the notary commits a criminal act. UUJN only regulates sanctions for violations committed by notaries against UUJN, such sanctions can be deeds made by notaries have no authentic power or only have power as deeds under the hands. Against the notary itself can be given sanctions in the form of reprimand to dismissal with disrespect.

c. The notary's responsibility is based on the Paraturan Of The Notary Department to the material truth in the deed he made. The notary's responsibility is mentioned in Article 65 of the UUJN which states that the notary is responsible for any deeds it makes, even though the notary protocol has been submitted or transferred to the notary protocol depositor.

$\mathrm{d}$. The notary's responsibility in carrying out the duties of his office based on the notary code of ethics. The relationship of the notary code of ethics and UUJN gives meaning to the position of notary itself. UUJN and the notary code of ethics require that notaries in carrying out their duties, in addition to having to submit to UUJN must also obey the notary code of ethics and must be responsible for the people it serves, notary organizations (Indonesian Notary Association or INI) as well as to the state.

Abdul Kadir Muhammad explained, Notary in carrying out his duties and position must be responsible, meaning: ${ }^{56}$

a. Notaries are required to make deeds correctly and adequately. This means that the deed made fulfills the will of the law and the request of interested parties because of their position.

b. Notaries are required to produce a quality deed. This means that the deed he made is following the rule of law and the will of the interested parties in the true sense, not far-fetched. Notary explained to interested parties the truth of the contents and

${ }^{56}$ Abdul Ghofur Anshori, Lembaga Kenotariatan..., p. 52 
procedures of the deed he made..

c. Positive impact, meaning anyone will admit the notary deed has the power of perfect evidence.

In addition, some prohibitions should be avoided by every notary. The prohibition against notaries is stipulated in Article 17 of Law No. 2 of 2014 on Amendments to Law number 30 of 2004 concerning Notary Positions, ${ }^{57}$ as follows:

a. running a position outside his or her office

b. leave the office area more than 7 (seven) consecutive working days without a valid reason

c. Concurrently as a civil servant

d. Concurrently a position as a state official

e. Concurrently as an advocate

f. concurrently a position as a leader or employee of a state-owned enterprise, a regionally owned business entity or a private business entity

g. concurrently a position as the Office of Land Deed Maker outside the notary department

h. become a substitute notary, or

i. perform other work contrary to religious norms, decency, or propriety that may affect the honor and dignity of notary positions.

\section{Notary Deed}

According to Sudikno Merokusumo, ${ }^{58} \mathrm{~A}$ deed is a letter as a signed means of proof that contains an event on which a right or engagement is based, which was initially created intentionally for proof. Proof is one

\footnotetext{
57 Pasal 17 Undang-Undang Nomor 2 Tahun 2014 tentang Jabatan Notaris

58 Sudikno Mertokusumo, Hukum Acara Perdata di Indonesia, (Yogyakarta: Liberty, 1981), p. 149
}

step in the civil case process. Proof is necessary due to a rebuttal or denial from the other party or to justify a right to dispute.

According to Subekti, a deed is a writing that is solely made to prove something of an event, hence a deed must be signed. Then, The Provisions of Article 1 paragraph (7) in UUJN state that a notary deed is made by or before a notary according to the form and ordinance of tang stipulated in this law. ${ }^{59}$

From some understanding of the deed, it is clear that not all can be called deeds, but only certain letters that meet certain conditions are called Deeds.

The conditions that must be met so that a deed is called proof is: ${ }^{60}$

a. The letter must be signed.

The necessity of signing a letter to be called a deed is specified in Article 1874 of the Civil Code. The purpose of the must be signed is to provide characteristics or to individualize a deed that is one deed with another, because the signature of each person has its characteristics that are different from the signatures of others. Moreover, with its signing it is considered to guarantee the truth of what is written in the deed.

b. The letter must contain events on which something is based or an engagement.

So the letter must contain a statement that can be the required evidence, and the legal event mentioned in the letter must be a legal event on which a right or alliance is based.

c. The letter was intended as a means of proof So the letter was deliberately made to be used as a means of evidence. According to

${ }^{59}$ Subekti, Pokok-Pokok Hukum Perdata, (Jakarta: PT. Intermesa, 1984), p. 178

${ }^{60}$ Subekti, Pokok-Pokok..., p. 178 
the provisions of Law number 13 of 1985 on Stamp Duty, in Article 2 it is determined among others that the letter of agreement and other letters made to be used as a means of proof of deeds, realities or circumstances of a civil law, notary deeds including copies are subject to stamp duty, the rate of which is regulated in Government Regulation number 24 of 2000, that is Rp.6,000 and a tariff of Rp.3,000,- (as the document outlined in the regulations above).

Based on the terms and conditions mentioned above, the sale and purchase letter, rental letter, even a receipt is a deed, because it is made as evidence of a legal event and signed by the interested.

A Notary deed is an authentic deed, a writing deliberately made to prove a particular event or legal relationship. As an authentic deed, made in the form prescribed by the Law (Article 38 UUJN), is made before authorized officials (public servants) and in the place where the deed is made, then the notary deed provides complete and perfect evidentiary power for the parties who make it. The perfection of the notary deed as a means of proof, then the deed must be seen as is, does not need to be judged or interpreted otherwise, other than that written in the deed. ${ }^{61}$

A notary deed is the agreement of the parties that binds them that makes it, therefore the legal terms of the agreement must be fulfilled. ${ }^{62}$ Article 1320 of the Civil Code which regulates the terms of the validity of the agreement, there are subjective conditions that relate to the subject who entered into or made a treaty, which consists of the word agreed and able to act to perform a legal act, and objective conditions that are conditions relating to the agreement itself or related to

\footnotetext{
${ }^{61}$ Subekti, Pokok-Pokok..., p. 180

62 Subekti, Pokok-Pokok..., p. 180
}

the object made a legal act by the parties, It consists of a particular thing and a cause that is not prohibited. ${ }^{63}$

As a result of specific laws, if subjective conditions are not met, the agreement may be void as long as there is a request from specific persons or interested ones. This objective condition if not fulfilled, then the agreement is null and void, without the need for a request from the parties, thus the agreement is considered to have never existed and is not binding on anyone. The subjective terms of the agreement are included in the notary deed in the beginning of the deed and the objective conditions are included in the Deed Body as the Content of the deed, the content of the deed is the embodiment of Article 1338 of the Civil Code regarding freedom of contract and provides legal certainty and protection to the parties regarding the agreements it makes. ${ }^{64}$

Thus, if at the beginning of the deed, especially the conditions of the parties facing the notary do not meet subjective conditions, then it may be canceled at the request of that particular person. If the contents of the deed do not meet objective requirements, it is considered to cancel the entire body of the deed, including canceling the objective conditions. Subjective conditions are placed as part of the beginning of the deed, arguing that although subjective conditions are not met as long as there is no filing of cancellation by way of a lawsuit from particular persons, then the contents of the deed containing objective conditions remain binding on the parties, this is different if the objective conditions are not met, then the deed is considered never to exist.

Notary deeds must be made in a form that has been determined by law. This is one of

63 Habib Adjie, Sekilas Dunia Notaris dan PPAT Indonesia, (Bandung: Mandar Maju, 2009), p. 37

${ }^{64}$ Habib Adjie, Sekilas Dunia..., p. 37 
the notary deed characters. The notary deed framework shall place subjective and objective conditions of notary deeds following the meaning of an agreement null and void. ${ }^{65}$

Based on its form, the deed is divided into authentic deeds and under-the-hand deeds. The basis of the law is Article 1867KUH Civil that is:

a. Authentic Deed. An authentic deed is a deed made by an official authorized to it by the ruler, according to the established provisions, either with or without the assistance of the interested, which records what is required to be contained in it by the interested. The authentic deed mainly contains the description of an official, who explains what he does and is seen in front of him. ${ }^{66}$

In articles $165 \mathrm{HIR}$ and $285 \mathrm{Rbg}$, an authentic deed is a deed made by or before an official authorized to do so, is complete evidence between the parties and their heirs and those entitled therely to it about those listed therein and even as mere notice, but the latter is only told it relates to the matter of the deed. The intended office includes Notaries, Clerks, Clerks, Civil Registry Officers, Judges, and many more.

In Article 101 paragraph (a) of Law No. 9 of 2004 on State Administrative Justice, states that an authentic deed is a letter made by or in the presence of a general official, who according to the laws and regulations is authorized to make the letter to be used as a means of evidence about the legal events or events listed therein.

The primary authority of the Notary is to make an authentic deed, in order for a deed to have its authenticity as an authentic

\footnotetext{
${ }^{65}$ Habib Adjie, Sekilas Dunia..., p. 37

66 Sudikno Mertokusumo, Hukum Acara Perdata Indonesia, (Yogyakarta: Liberty, 1981), p. 110
}

deed, it must fulfill the provisions as an authentic deed stipulated in Article 1868 of the Civil Code, namely: ${ }^{67}$

1) The deed must be made by (door) or in the presence (tenberstaan) of a general official, which means notary deeds whose contents regarding deeds, agreements and provisions must make the Notary a general office.

2) The deed must be made in the form prescribed by law, then if a deed is made but does not meet this requirement it loses its authenticity and only has the power as a deed under the hand when comparantens sign the deed..

3) The general office by or before the deed is made, shall have the authority to make the deed, for a Notary can only perform or exercise his office within the jurisdiction prescribed to him. If the Notary makes a deed outside the jurisdiction of his office then the deed he made becomes invalid.

According to C.A.Kraan, authentic deeds have the following characteristics: ${ }^{68}$

1) A writing is deliberately made solely to be used as evidence or a proof of the circumstances as mentioned in the writing made and declared by the competent authority. The letter is also signed by or only signed by the relevant official.

2) Until there is evidence to the contrary, a letter is thought to have come from an authorized official.

3) Provisions of the laws and regulations that must be met; the provision regulates

67 Sudikno Mertokusumo, Hukum Acara Perdata Indonesia..., p. 10

${ }^{68}$ Herlien Soerojo, Kepastian Hukum Hak Atas Tanah di Indonesia, (Surabaya: Arkola, 2003), p. 148 
the procedure for making it (at least contains provisions regarding the date, place of the deed of writing, name and position or position of the office that makes it).

4) An official appointed by the state and has an independent and impartial nature and occupation in carrying out his position.

5) The statement or fact of the action referred to by the official is a legal relationship in the field of private law.

b. Deed under the hand. An under-hand deed is made and signed by the parties who agree in the engagement or between the interested parties only.

According to Sudikno Mertokusumo, the deed under the hand is a deed that is deliberately made for proof by the parties without the help of an official. So it is solely made between interested parties. ${ }^{69}$

In Article 101 paragraph (b) of Law No. 9 of 2004 on State Administrative Justice, states that the deed under the hand is a letter made and signed by the parties concerned with the intention to be used as a means of evidence about the events or legal events contained therein.

Article 1874 of the Civil Code states that what is considered writing under the hand is a deed signed under the hand, letter, list, letter of household affairs, and other writings made without the intermediary of a general official. The deeds under the hands include: ${ }^{70}$

1) Legalization, i.e. deeds under the hands that have not been signed, is given to the

69 Sudikno Mertokusumo, Hukum Acara Perdata di Indonesia, (Yogyakarta: Liberty, 1998), p. 125

${ }^{70}$ A. Kohar, Notaris Berkomunikasi, (Bandung: Aumni, 1984), p. 34
Notary and in the presence of the Notary signed by the parties concerned, after the contents of the deed are explained by the Notary to them. On legalization, his signature was done in the presence of legalization.

2) Waarmerken, which is an under-hand deed that is registered to give a definite date. The signed deed is given to the Notary to be registered and given a definite date. Waarmerken does not explain who signed and whether the signer understood the contents of the deed. There is only certainty of the date and no certainty of signature.

\section{The Legal Power of Notary Deeds}

The discussion of the legal power of notary deeds can be connected with the legal power of authentic deeds because given the relationship with the notary function, the classification of notary deeds. The power of the notary deed and the authentic deed is a direct result which is a necessity of the provisions of the legislation, that there must be authentic deeds as a means of proof and the duties imposed by law on certain officials or persons.

When considered article 164 HIR and article 1865 of the Civil Code, it is clear that the written evidence is placed at the top of all other evidence mentioned in the articles of the Law. Although the order of mention of evidence in the provisions of the Law is not imperative, it can be said that the proof of writing (deed) is indeed an appropriate and essential evidence tool. ${ }^{71}$

Subekti says, "in an advanced society, the most appropriate signs or evidence are indeed writing". In essence, the evidentiary power of

\footnotetext{
${ }^{71}$ Victor M. Sitomorang, Grosse Akta Dalam Pembuktian Dan Eksekusi, (Jakarta: PT Rineka Cipta, 1993), p. 108
} 
the deed is distinguished from three, namely:

a. The power of proof is born. What is meant by the power of proof of birth is the power of proof based on the state of birth of the deed, meaning that a letter that looks like a deed must be treated as a deed, until its authenticity is done. The power of proof born of this authentic deed applies to the benefit or interests of each person and is not limited to the interests of the parties only, where the signature of the official who signed the deed is accepted its validity. ${ }^{72}$

b. Formil's power of proof. The power of formal proof is based on whether or not there is a statement by the signed under the deed. In an authentic deed, the deed-making official states in the writing that there is stated in the deed as it has been listed in it. In the case of formal proof, the things that need to be listed are the date of the deed, the place of making the deed, and the authenticity of the signatures of officials and parties and witnesses who also signed the deed. ${ }^{73}$

c. Material Power of Proof. In the case of this material proof, it concerns the proof of the material of a deed, giving certainty about the events that officials and parties perform or carry out as described in the deed. ${ }^{74}$

\section{Division of Inheritances Based on Notary Deeds}

Copy of deed

\section{a. Inheritance Division Deed Number 19}

From this notary deed it is known that on July 16, 2018, it has faced H. Mufti Nokhman, SH., namely Rosdiana, Harita and Hardi. Based on the testimony of the heirs, that the interceptors were the biological

\footnotetext{
${ }^{72}$ R. Subekti,Hukum Perdata, (Jakarta: PT Inter Masa, 1992), p. 85

${ }^{73}$ R. Subekti,Hukum Perdata..., p. 85

${ }^{74}$ R. Subekti,Hukum Perdata..., p. 85
}

children of the late Abdul Hamid and the deceased $\mathrm{Hj}$. Halima, and also explained that the deceased Abdul Hamid and the deceased Hj. Halima did not leave a will.

It is also known that the deceased $\mathrm{Hj}$. Halima left a relic in the form of two plots of land located in the Pedati Market Village covering an area of $5,583 \mathrm{~m} 2$ and in the Transverse Market Village covering an area of $201 \mathrm{~m} 2$. Then the heirs agreed to divide the relics of the deceased $\mathrm{Hj}$. Halima as follows: ${ }^{75}$

1) Hardi gets part or half of the land located in Pasar Pedati Village.

2) Harita gets part or half of the land located in Pedati Market Village.

3) Rosdiana got a piece of land located in the Transverse Market Village.

The heirs in the deed stated to guarantee the truth of the letters and the identity of each. Then, there were also two witnesses in the deed of inheritance division.

\section{b. Statement Deed No. 33}

From this notary deed it is known that on February 22, 2018 has faced H. Kuswari Ahmad, SH., M.Kn., namely Aisah, Nur Hasanah, A. Mirzan and Rina Pasia Wati. The interceptors were the heirs of the deceased Rifa' $i$ and no other heirs. The late Rifa'i also did not leave a will. It is known that the deceased Rifa'i left an inheritance in the form of a piece of land that had been certified covering an area of $1,779 \mathrm{~m} 2$ and 35 cows. $^{76}$

Then, the heirs agreed to divide the relic, into the following: ${ }^{77}$

75 Notaris H. Mufti Nokhman, Akta Pembagian Warisan No.19, p. 3

${ }^{76}$ Notaris H. Kuswari Ahmad, Akta Pernyataan Nomor 33, p. 2

${ }_{77}$ Notaris H. Kuswari Ahmad, Akta Pernyataan Nomor 33 , p. 3 
1) Aisah got 15 cows.

2) Nur Hasanah got a plot of land covering an area of $1,779 \mathrm{~m} 2$, which is empty land.

3) A. Mirzan got 12 cows.

4) Rina Pasia Wati got 8 cows.

The heirs in the deed stated to guarantee the truth of the letters and the identity of each. Two witnesses were presented in the statement.

\section{c. Statement Deed No. 69}

Based on the information in this deed, on March 3, 2017 has been present before Rizfitriani Alamsyah, SH., namely Muchari, Budiman, Sri Hastuti and Surya Ramadan. The interceptors are the heirs of the late Muchtar Hasan who died in 2012 and the deceased Rismiwati Binti A. Rahim, who died in 2003. It is known that there are no other heirs other than the interceptors. Then the late Muchtar Hasan and the deceased Rismiwati Binti A. Rahim left an inheritance in the form of a plot of land covering an area of 7,374 $\mathrm{m} 2$, located in Pal 30 Village, Lais Subdistrict, North Bengkulu Regency.

Then, the heirs agreed to divide the only relic, into the following: ${ }^{78}$

1) Muchari gets approximately $1,500 \mathrm{~m} 2$, which is empty land.

2) Budiman gets approximately $1,500 \mathrm{~m} 2$, which is empty land.

3) Sri Hastuti gets approximately $2,874 \mathrm{~m} 2$, following the buildings above it.

4) Surya Ramadan gets approximately 1,500 $\mathrm{m} 2$, which is a wasteland.

The heirs in the deed stated and confirmed to have accepted and approved voluntarily the

78 Notaris Rizfitriani Alamsyah, Akta Pernyataan Nomor 69, p. 3 distribution of the heirs' parents' inheritance. Two witnesses were presented in the statement.

\section{d. Statement Deed No. 95}

Based on the description in this deed, that on December 2, 2019 has faced H. Kuswari SH, M.Kn., namely Mayuna, Eli Sumarni, and Kalpen Mardani. The interceptors are the rightful heirs of the deceased Muktarudin who died in 2012. It is known that the deceased Muktarudin left an inheritance in the form of two plots of land that have been certified, covering an area of $18640 \mathrm{~m} 2$ and $19850 \mathrm{~m} 2$ respectively, all of which are registered in the name of the deceased Muktarudin. ${ }^{79}$

Later, the heirs agreed to hand over the two plots of the estate to Eli Sumarni. The heirs in the deed also state that guarantee the truth of the letters and the identity of each. Two witnesses were presented in the statement.

Based on the author's interview with the heirs of the late Abdul Hamid and the deceased Hj. Halima, namely Rosdiana and Harita $^{80}$ It can be known that the division of heirs as outlined in inheritance division deed Number 19, which is the division for Rosdiana is more excellent in value when compared to other heirs, because while their parents are still alive, Rosdiana who accompany, care for and care for their parents. The creation of the deed is also intended so that the ownership of the house occupied by Rosdiana and her husband becomes clearer.

Then based on the results of the author's interview with the heirs of the deceased Rifa'i, namely Aisah, Nur Hasanah, Rina Pasia Wati and A. Mirzan, that the division of heirs as outlined in Deed Of Statement No. 33 obtained

\footnotetext{
${ }^{79}$ Notaris H. Kuswari Ahmad, Akta Pernyataan Nomor 95 , p. 3

${ }^{80}$ Interview with Rosdiana and Harita, Heirs, June 12, 2020.
} 
data that Aisah as the deceased's wife got the inheritance of 15 cows as savings if there is an urgent need. ${ }^{81}$ Daily needs are the responsibility of A. Mirzan and Rina Pasia Wati, While Nur Hasanah got the land because Nur Hasanah had set up a house on this plot of land that until now was occupied by Aisah. While A. Mirzan and Rina Pasia Wati have felt enough with their respective parts. ${ }^{82}$ Aisha has also made the joint property in marriage with the deceased into a unity and an inseparable part of the inheritance.

Then the results of the author's interview with the heirs of the late Muchtar Hasan and the deceased Rismiwati Binti A. Rahim, namely Muchari, Sri Hastuti and Surya Ramadan (Budiman at the time the author of the interview had died on April 19, 2018), the division of heirs as outlined in Deed Of Statement No. 69, it can be known that the consideration of Muchari and Surya Ramadan, ${ }^{83}$ His part for Sri Hastuti is more significant, because in addition to being the only daughter in the family who has taken care of her father, namely the late Muchtar Hasan in the house during his father's illness and death, Sri Hastuti also managed a grocery store business built and run by the deceased, so that it became a source of family income until now.

Furthermore, the author's interview with the heirs of the deceased Muktarudin, namely Mayuna, Eli Sumarni, and Kalpen Mardani, the division of heirs as outlined in Deed Of Statement No. 95, it can be known that Mayuna and Kalpen Mardani, ${ }^{84}$ releasing their respective share of the inheritance, so that it

${ }^{81}$ Interviewed with Aisah, Heir, June 21, 2020.

${ }^{82}$ Interviewed with Nur Hasanah, Heir, June 21, 2020.

${ }^{83}$ Interviewed with Muchari dan Surya Ramadhan, Heirs, May 31, 2020.

${ }^{84}$ Interviewed with Mayuna and Kalpen Mardani, Heirs, June 19, 2020. belongs to Eli Sumarni, in addition to fulfilling all the needs of life Mayuni and Kalpen Mardani during this time is Eli Sumarni, he also bears all the medical expenses of the deceased during illness, and for the purchase of the two plots of land is also assisted from Eli Sumarni. ${ }^{85}$

The process of making such deeds can be explained that starting from the arrival of one or more of the heirs to the Notary office, and explaining the meaning of their agreement as heirs in connection with the division of the inheritance of the deceased / deceased parents to be poured in the form of notary deeds (notaries). After the heirs complete the necessary documents, including (but not limited to) death certificates, inheritance certificates, identities of all heirs and inheritance documents to be shared, the Notary prepares a deed to be signed and then arranges the day of signing. Then on the appointed day, all heirs come to the notary's office to sign the deed in question, then the deed is read and reaffirmed by the Notary of the truth of the agreement of all heirs as stated in the deed. After all the heirs agreed with the contents of the deed, then they signed the deed. Furthermore, the Notary immediately issues a copy of the deed that is only signed by the Notary concerned to be submitted to the heirs, while the deed that the heirs have signed is called "Minuta" along with the completeness of data such as photocopies of identity data of heirs and interceptors, death certificates, heir certificates and photocopies of shared inheritance data, will be stored by Notaries.

Based on the information of the heirs who almost the same said that basically, the creation of the inheritance deed aims to clarify and strengthen their respective parts, so that the right of ownership of the inheritance following

${ }^{85}$ Interviewed with Eli Sumarni, Heir, June 20, 2020. 
the agreed part in order to be utilized better and avoid disputes between heirs, descendants of heirs and others.

Likewise, it can also be known that the division of heirs written in the notary deed makes the heirs remain in harmony and there is no dispute or dispute, especially up to the legal process in the Court relating to the division of heirs made in the deed.

From the presentation of the above data it can be known that the heirs in dividing the relics do not use the Islamic inheritance system as stated in surah an-Nisa' verses 7-8, and surat An-Nisa' verses 13-14:

From the provisions of the two verses above clearly shows the command from Allah Swt that Muslims in carrying out the distribution of inheritance must be based on the provisions of the Qur'an. Regarding the provisions of the division of inheritance has been explained in the Qur'an surah AnNisa' verses 11 and 12. Judging from the contents of these verses, it shows that the legal provisions on the inheritance section for each heir $(1 / 2,1 / 3,1 / 4,1 / 6,1 / 8$, and $2 / 3$ and asobah) are provisions that are final and cannot be changed anymore.

From the exposure of the above data it can be known that the heirs in dividing the relics do not use the Islamic inheritance system as stated in Surah An-Nisa' verses 7-8. The division of inheritance is carried out familially by the heirs in the notary deed above. The division of inheritance in a familial manner is how each side consults each other to find a way out of the inherition problem faced. Regarding the settlement of the division of inheritance based on deliberation and agreement of the heirs is considered a wise solution.

\section{Division of Inheritances Based on Notary Deeds}

Notary based on the laws and regulations is a general official authorized to make authentic deeds, one of which is the deed of separation and division of inheritance. Authentic deeds as evidence have an essential role in every legal relationship in people's lives. Through authentic deeds made by notaries, determine the rights and obligations of the parties and ensure legal certainty and at the same time are expected to avoid the occurrence of disputes. Although the dispute is inevitable, in its completion, an authentic deed that is the most vital written and proof tool that contributes concretely to the solution of cases cheaply and quickly.

Notaries can make inheritance division deeds not only based on the civil law, but can also make inheritance division deeds based on the provisions of Islamic inheritance law. Notary authority in making deeds of inheritance division according to the provisions of Islamic law, in addition to having to meet the applicable laws regarding the position of Notary, Compilation of Islamic Law and elements of the legal terms of the agreement in Islam, as well as regulations related to inheritance issues, and fulfilling the provisions stipulated in Islamic inheritance law derived from the Qur'an, Hadith and ijtihad ulama.

Generally the Deed of Inheritance division is made as evidence of anyone (heir) acting on the property of someone who has died so that the heirs transfer the right to an inheritance as a condition in the making of another deed or made to determine the part of each heir.

In terms of proof of the Inheritance Division Act has an excellent proof value because it is made before the competent authority (Notary), but the Deed of Inheritance Division does not have perfect evidentiary power, if it does 
not qualify as a deed and not the authority of a Notary. Then, the Deed of Inheritance Division if it turns out that the contents are not accurate, it is the responsibility of the parties facing the Notary, and does not need to involve a Notary. As long as a notary deed cannot be proven to be accurate, then the deed is an authentic deed that contains essential information from the parties who state their information in the authentic deed and it is supported by valid documents and witnesses who can be accounted for following the provisions of applicable laws and regulations.

The conditions that must be met so that the Deed of Inheritance Division is called proof is:

a. The deed must be signed in the Presence of a Notary. The purpose of the must be signed is to provide characteristics or individualize a deed that is one with another deed. With its signing before the Notary, the Notary guarantees the truth of the agreement from what is written in the deed.

b. The act must contain events on which a right or alliance is based. So the deed must contain a statement that can be the required evidence, and the legal event mentioned in the deed must be a legal event on which a right or alliance is based..

c. The act is intended as a means of proof.

So the deed was deliberately made to be used as a means of evidence. According to the provisions of Law number 13 of 1985 on Stamp Duty Rules, in Article 2 it is determined among others that the letter of agreement and other letters made to be used as a means of proof of deeds, realities or circumstances of a civil law, notary deeds including copies are subject to stamp duty, the rate of which is regulated in Government Regulation number 24 of 2000 .

Based on the data that the authors obtained in the study, that:
1. Notary H. Mufti Nokhman, SH. (Inheritance Division Deed No. 19)

Heirs in dividing the relics do not use the Islamic inheritance system, where boys get twice the share received by girls. However, inheritance is divided by the order in which the child is born. Rosdiana was the eldest child born on September 23, 1968. So, he got an inheritance that is a part of the land located in the Transverse Market Village. Then, the second child, Harita who was born on October 5, 1973 and the youngest child, Namely Hardi who was born on August 9, 1980 get each half of the land located in Pasar Pedati Village.

2. Notary H. Kuswari Ahmad, SH., M.Kn. (Deed of Statement No. 33)

The division of inheritance above also does not use the provisions in faraidh. Aisah is the wife of the deceased, then A. Mirzan is the first child born in 1978, Nur Hasanah the second child was born in 1980 and Rina Pasia Wati is the youngest child born in 1982. Suppose the division of inheritance is based on the provisions of Islamic law. In that case, Aisha as a wife certainly gets more share of the property, because the wife also gets joint property. However, the property together with the deceased becomes a unit with the heritage, so that the inheritance is done familially with various aspects that are considered.

3. Notary Rizfitriani Alamsyah, SH. (Statement Deed No. 69)

Heirs dividing inheritances do not use Islamic inheritance law, but heirs agree to divide inheritances based on gender i.e. the only daughter gets more share. It can be seen from the data above that Sri Hastuti got the most parts among other heirs, namely a plot of land covering an area of approximately $2,874 \mathrm{~m} 2$ and buildings 
above it. While the three male heirs, each gets a plot of land covering an area of approximately $1,500 \mathrm{~m} 2$.

4. Notary H. Kuswari Ahmad, SH., M.Kn. (Deed of Statement No. 95)

In this case, the heirs did not divide the inheritance equally, or by gender or under Islamic law. The division of the above inheritance is done based on agreement and sincerity of the heirs to give and relinquish the rights to the share of each heir to one of the heirs only, namely Eli Sumarni who obtained two certified plots of land covering an area of $18640 \mathrm{~m} 2$ and $19850 \mathrm{~m} 2$.

From the exposure of the above data it can be known that the heirs in dividing the relics do not use the Islamic inherition system as stated in surah an-Nisa' verses 7-8. The division of inheritance is carried out familially by the heirs in the notary deed above. The division of inheritance in a familial manner is how each side consults each other to find a way out of the inherition problem faced. Regarding the settlement of the division of inheritance based on deliberation and agreement of the heirs is considered a wise solution.

Saad al-dzari'ah prevents, forbids, closes roads or isimates a work that was initially allowed, but because it can cause something that causes damage or something that is prohibited, then it becomes forbidden to do, if the was said a work leads to damage then it becomes prohibited, one of the rules is:

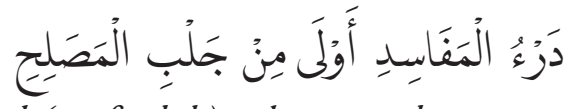

"Rejecting evil (mafsadah) takes precedence over attracting good (maslahah).”

When mafsadat and maslahat fight for places, then the act of avoiding mafsadat must be seeded, although it results in the benefit of a benefit, because the Islamic sharia has more attention to the things that are forbidden (al-manhiyyat) than the attention given to the things that are ordered (al-ma'murat). Avoidance is a concrete form of prohibition. In the rules of fiqh explained:

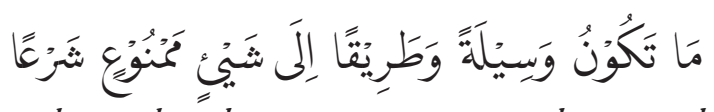
"Something that becomes an intermediary and a way to something forbidden by syara, then the law is forbidden."

That Dzariah is a washilah (way) that conveys to the destination both halal and haram. So the way or way that conveys to the haram the law is haram, on the contrary the way or way that conveys to the halal the law is also halal. Indeed all the purposes of syara are to benefit people and reject mafsadat from them, it is impossible, except through the causes conveyed to them. So it is necessary to do these causes, because that is the cause of the purpose or purpose. Thus, it can be established that works that deliver to benefit, are required to do them, and works that deliver on damage and welfare are forbidden.

The division of inheritance is closely related to justice. The concept of justice in Islamic inheritance law is granting rights and obligations to everyone entitled to receive them. The wisdom of giving a man's inheritance is twice the amount of inheritance received by women because men in addition to financing their own lives are also obliged to provide for their families. In addition, justice in Islamic inheritance is also based on the principle of balanced justice, so that in some cases the division of certain inheritances, the female part can equal the male part or exceed it.

The implementation of family inheritance division is widely pursued, both based on applicable customs and their respective economic conditions. In addition to being considered to reflect togetherness and realize 
justice, it can simultaneously strengthen the friendship between families and create benefits for all heirs so as not to dispute (mafsadat).

This is following Surah Al-Baqarah verse 195:

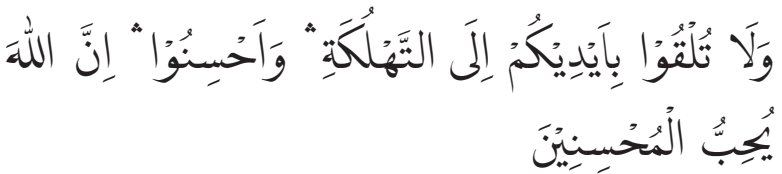

"...And do not throw yourself into perdition, and do good, for Allah loves those who do good."

The purpose of the above verse is that man should not surrender himself to the things that cause harm, but close the hope with something that can bring good. The maslahat must aim to maintain something dharuri and eliminate difficulties (raf ul haraj) by eliminating masyaqat and madharat on the condition that the maslahat must be following maqasid al-shari'ah (the purpose of the law).

The creation of the Inheritance Division Act is the community's need as a means of evidence that proves itself as an heir. A means of proof must be made in writing by pouring the desire to be expressed into a deed of statement made in written form. The creation of this deed aims in the future there is no denying what has been mutually agreed as an agreement.

In sadd al-dzari'ah there are three things to consider. First, it is about purpose. If the goal is forbidden, then the road is forbidden and if the purpose is mandatory, then the road is required. Second, it concerns the intention (motive). If the intention is to achieve the halal, then the law of the means is halal, and if the intention to be achieved is haram, then the means are haram. Third, the consequences of an act. Based on the sadd adz dzari'ah method, the function of making the notary deed is:

\section{Avoiding The Division of Islamic Inherition}

The inheritance of Islam has made provisions regarding inheritance that is very good, wise and just. The provision relates to the transfer of property belonging to a person left behind after death to his heirs, both female and male. The provisions of the inheritance law are sourced in QS. An-Nisa' (4) verse 11:

God does not give a written explanation for the wisdom behind the secret of balance 2: 1 for male heirs and female heirs, even though both have the same position in the sense of equality and equality in terms of kinship. That the difference in the share of the inherition between men and women is primarily based on consideration of the differences in their respective functions in which men are burdened with the responsibility to maintain, protect and work hard for women, and serve their wives, or broadly speaking men struggle to the point of final blood also for the sake of self-service to women (wives or mothers of their children).

According to Ali al-Shabuni, the wisdom of folding the same share of a man's inheritance with the share of two daughters is because the need for a boy to finance his home life is much greater than the property needed by a girl. He needs more financing of life and several obligations (responsibilities) that are more severe than the responsibilities of women. Therefore, men need wealth more than women.

Thus, the more significant part of the son than the part of the daughter, is inseparable from the son's status who will in time become the husband of his wife, or even the father of his children. On the contrary, the daughter will be the wife of the husband or the mother of her children, who will most likely receive a living from the husband or father of her children. 
The application of sadd al-dzariah in this regard, specializing in means that can lead to the forbidden. Thus, the division of inheritance in Islam is legally obligatory, but because the means are feared to lead to acts that contain danger, then the division of Islam is replaced by agreement (family division).

The division of inheritance in a familial manner is done by each side to consult each other to find a way out of the inherition problems faced. Regarding the settlement of the division of inheritance based on deliberation and agreement of the heirs is a wise solution.

In all matters of world affairs, human beings are encouraged always to consult so that later they can produce a determination that is considered fair from each concerned. Deliberation is a negotiation activity by exchanging opinions from various parties on a problem to be considered and decided and taken the best for the sake of mutual benefit. This is based on surah al-Shura verse 38 which reads:

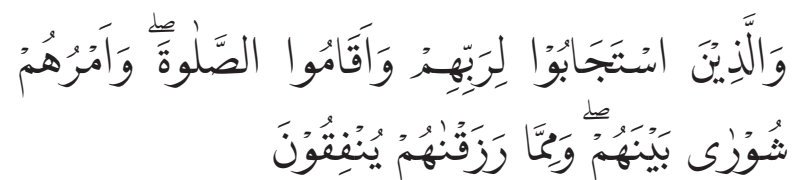

"And (for) those who accept (obey) the cry of their Lord and establish prayers, while their affairs (are decided) by deliberation between them; And they gave them some of the sustenance we gave them."

In the above verse, God encourages man to consult in deciding or establishing all things in the form of worldly affairs. According to Imam Jalaludin, lafadz (in their affairs) relating to themselves (they decide between them by deliberation) decided it deliberatively and was not hasty in deciding. ${ }^{86}$
According to M. Quraish Shihab ${ }^{87}$ they decide through deliberation, none of them are authoritarian by imposing their opinions. Al-Maraghi ${ }^{88}$ They say that when they have a business, they may consult with them to be discussed and studied.

In Islam, deliberation is a noble and essential practice, because Allah forbids his servants to scatter and quarrel. As in Surah Ali-Imran verse 103 Allah swt says:

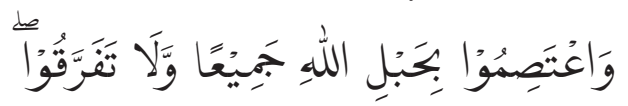

"And hold all of you to the ropes of Allah, and do not be scattered...."

So that in some cases the division of inheritance on the notary deed above, the female part can equal the male part or exceed it, because it is divided by agreement (family), not in the inheritance of Islam.

\section{Avoiding Slander and Injustice}

Concerning economic justice, that justice in the economic field in principle the property should not be centered on the aghniya (rich) group alone as stated in surah al-Hasyr: 7 . If there is a concentration of wealth, then there will be social inequality, there will be poverty and the process of impoverishment.

According to Ibn Qayyim, justice can be felt in all aspects of life. ${ }^{89}$ Justice is the objective of sharia. This is because sharia contains justice, blessing and wisdom. Ibn Qayyim argued that the wealth possessed by a person allows him to carry out all kinds of good deeds easily.

The application of sadd al-dzariah in this case, concerns intention (motive). If the intention is to achieve the halal, then the law

\footnotetext{
${ }^{87}$ M. Quraish Shihab, Tafsir al Misbah..., p. 665

88 Al-Maraghi, Ahmad Musthafa.Tafsir Al-maraghi. (Semarang: PT. Karya Toha Putra. 1993), p. 335

${ }^{89}$ Ibnu Qayim al-Jauzuyah, I'lam al-Muwaqqiin, (Beirut: Dar al-fikr, tt) p. 2
} 
of the means is halal, and if the intention to be achieved is haram, then the means are haram. The motive (intention) of the perpetrators to divide inheritance in a familial (agreement) is to achieve justice and avoid slander between them, so that the division of agreement (means) is legally halal because the purpose is also halal.

Based on the agreement, complete awareness and sincerity of the heirs, the amount of each heir's share can change according to the agreement of the heirs. Even an heir may give up his or her right to be granted to another heir based on objective and rational considerations. Regarding the settlement of the division of inheritance by the heirs, which is based on deliberation and agreement is a wise solution in addressing the gap in the economic conditions of the heirs. Theoretically, heirs who get a large share, can leave their share to other heirs with a smaller share whose economic conditions are concerning.

\section{Prevent hostility in the family}

In specific communities, a system of peaceful division is widely pursued based on applicable customs and their respective economic conditions. In addition to being considered to reflect togetherness and realizing justice, it can simultaneously strengthen friendship among families. Islam teaches people to always live in harmony between family members.

Islam is a religion of peace and love of peace, Islam always guides its ummah to maintain harmony between one individual and another. In the teachings of Islam that all human beings are brothers regardless of differences (Q.S. Al-Hujurat: 10)

According to Imam Jalaludin, the meaning of "the believers are brothers" emphasizes the meaning of brothers in the like. Then, "Therefore peace your two brothers" if they both dispute. According to the other qiraat read ikhwatikum, meaning your brothers. "And fear Allah so that you may have mercy. ${ }^{90}$ After the previous verse ordered peace between two groups of believers. This verse explains why we have to reconcile it. Since we are brothers and sisters even though they are not one descendant, then another group that is not directly involved in the dispute between the groups, peace even if the dispute only occurs between your two brothers. ${ }^{91}$

Sayyid Qutb also added that this brotherhood implies that love, peace, cooperation and unity should be the main foundation of Muslim communities and should remind each other to always be in the way of Allah in a wiser way. ${ }^{92}$

The heirs in the notary deed above try to maintain harmony related to the division of inheritance. Division is done peacefully so that between them there is nothing that does not envy each other, and hates each other with the least amount of inheritance that each receives.

The application of sadd adz-dzari'ah in this case, also concerns intention (motive). If the intention is to achieve the halal, then the law of the means is halal, and if the intention to be achieved is haram, then the means are haram. The motive (intention) of the perpetrators to share inheritance in a familial manner (based on agreement) is to prevent hostility in the family. Thus, the division of inheritance in a familial manner is a means to achieve the goal, the law is halal because the goal is also halal, which is to avoid hostility.

${ }^{90} \mathrm{Al}$ Mahalliy, Imam Jalaludin, Tafsir Jalalain Berikut Asbabun Nuzul Ayat Surat az Zumar s.d. Surat an Nas. (Bandung: Sinar Baru, 1990), p. 2235

${ }^{91}$ M. Quraish Shihab, Tafsir al Misbah (Pesan dan Kesan dari Keserasian al Quran), (Jakarta: Lentera Hati, 2012), p. 598-599

92 Sayyid Quthb, Tafsir Fi Zhilalil Qur'an Di Bawah Naungan Al Qur'an (Surat ash Shaffaat 102-al Hujarat), (Jakarta: Gema Insane press, 2004), p. 417 
4. Prevent disputes from happening in the future

The importance of heirs makes the Deed of Inheritance division as evidence of anyone (heir) acting on the property of a person who has died so that the heirs transfer the right to an inheritance as a condition in the making of another deed or made to determine the part of each heir.

In terms of proof of the Inheritance Division Act has an excellent proof value because it is made before the competent authority (Notary), but the Deed of Inheritance Division does not have perfect evidentiary power, if it does not qualify as a deed and not the authority of a Notary. Then, the Deed of Inheritance Division if it turns out that the contents are not accurate, it is the responsibility of the parties facing the Notary, and does not need to involve a Notary. As long as a notary deed cannot be proven to be accurate, then the deed is an authentic deed that contains essential information from the parties who state their information in the authentic deed and it is supported by valid documents and witnesses who can be accounted for following the provisions of applicable laws and regulations.

Islam always encourages its people to record every muamalah practice. This is contained in qur'an al-Baqarah verse 282. God's advice to record it aims to avoid unwanted things against parties who are bound by the contract, because it does not rule out the possibility that if a treaty is not recorded, then in the future, there is some betrayal of one of the parties.

The application of sadd adz-dzari'ah in this case, concerns intention (motive). If the intention is to achieve the halal, then the law of the means is halal, and if the intention to be achieved is haram, then the means are haram. The motive (intention) of the perpetrators to share the inheritance in a familial (agreement) is to prevent disputes in the future. Thus, the division of inheritance in a family (means) of the law is halal because the purpose is also halal to avoid future disputes.

According to the author, the implementation of the division of inheritance in a familial manner, is not intended to avoid furudh almuqaddarah (the part arranged in nash), but nothing but for the benefit of all heirs and avoidance.

To formulate the criteria of maslahat itself is very important. Considering Islamic law always see good as one of the guidelines in establishing the law. Imam Malik provides the following criteria for maslahat: ${ }^{93}$

First, the maslahat is ma'qul (rationable) and munasib (relevant) with the established legal case. Second, the maslahat must aim to maintain something daruri and eliminate difficulties (raf ul haraj) by eliminating the third masyaqat and madharat, the maslahat must be following the maqasid al-shariah (the purpose of the disyari'atnya law) and not contrary to the proposition of syara' which qath'i.

Meanwhile Al-Ghazali formulated maslahat as follows: first, the benefit falls into the category of dharuriyyat rank, meaning that the maslahat should not threaten the existence of the five main elements of maslahat. That is, to preserve religion, soul, reason, descendants and wealth. Second, it must be qath'i. It means that his benefit is genuinely believed. Third, the benefit is kulli means that the benefit is collectively not individual. If the maslahat is individual, then the maslahat must be following the maqasid al-Syari'ah. ${ }^{94}$

Imam al-Syatibi put forth three conditions that must be fulfilled, so that the deed is

${ }^{93}$ Gibtiah, Perubahan Sosial Dan Pembaruan Hukum Islam Perspektif Sadd Al-Dzariah, Jurnal Nurani, Vol. 15, No. 2, Desember 2015: 101- 114, p. 107

${ }^{94}$ Gibtiah, Perubahan Sosial ..., p. 108 
forbidden, that is first, it leads to mafsadat muthlaq. Second, the mafsadat of the deed is stronger (quality) than the maslahatnya. Third, the mafsadat element in the deed is more (quantity) than its maslahat. Therefore, referring to the substance of sadd al-dzari'ah as an attempt to close the road leading to haram / forbidden by Islam as a preventive measure, then the division of inheritance in a family that aims to avoid the division of Islamic inheritance, avoid slander and injustice, prevent hostility in the family and prevent disputes in the future, this is acceptable. Because following the concept of sadd al-dzari'ah which will eventually benefit the heirs' individuals. So in the perspective of sadd al-dzariah, the position of making the deed of inheritance division can be changed from mubah to sunnah.

\section{Conclusion}

From the previous presentation, it can be concluded that the heirs in dividing relics in the notary deed do not use the Islamic inheritance system as stated in the Qur'an surah An-nisa' verses 7-8. The division of inheritance is done familially, namely by the way each side consults each other to find a way out of the inherition problem faced. Regarding the settlement of the division of inheritances based on the deliberations and agreements of the heirs, as stated in the deed made before a notary, and this is considered a wise solution because it can be used as a means of written evidence, both for the heirs and non-heirs From the previous presentation, it can be concluded that the heirs in dividing relics in the notary deed do not use the Islamic inheritance system as stated in the Qur'an surah An-nisa' verses 7-8. The division of inheritance is done familially, namely by the way each side consults each other to find a way out of the inherition problem faced. Regarding the settlement of the division of inheritances based on the deliberations and agreements of the heirs, as stated in the deed made before a notary, this is considered a wise solution because it can be used as a means of written evidence, both for the heirs and non-heirs.

Implementing the division of inheritance in a familial manner is not intended to avoid the dispossession or seizure of property arranged in nash), but none other than for the benefit of all heirs and avoiding the currence of disputes in the future. sTo prevent the occurrence of such impossibility, a deed of inheritance was made before a notary. So that in the perspective of sadd al-dzari'ah, the position of making the deed of inheritance division is sunnah.

\section{References}

Adjie, Habib. Hukum Notariat Indonesia. Bandung : PT Refika Aditama. 2008.

Adjie, Habib. Sekilas Dunia Notaris dan PPAT Indonesia. Bandung: Mandar Maju. 2009.

Al-Haolandi, Setya Qodar. Peran Notaris Dalam Pembagian Waris Berdasarkan Hak Waris Barat Dengan Peran Pengadilan Agama Dalam Pembagian Waris Berdasarkan Hak Waris Islam, Jurnal Akta, Vol. 5, No. 1, Maret 2018.

Ali, Zainuddin. Pelaksanaan Hukum Waris di Indonesia. Jakarta: Sinar Grafika. 2008.

Amin, Ma'ruf. Fatwa Dalam Sistem Hukum Islam. Jakarta : Elsas. 2008 .

Andiko, Toha. "Larangan Bercadar di Perguruan Tinggi Perspektif Sadd al-Dzari' ah", Jurnal Madania, Vol. 22, No. 1, Juni 2018.

Asmawi, Perbandingan Ushul Fiqh. Jakarta: Amzah. 2011.

As-Shabuni, Muhammad Ali. Hukum Kewarisan Menurut Al-Qur'an Dan Sunnah. Jakarta: CV. Diponegoro. 2004.

Athoillah, Mohammad. Fikih Mawaris. Bandung: Yrama Widya. 2013.

Basiq Djalil. Ilmu Ushul Figh, Jakarta: Kencana Group. 2014. 
Budiyanto, Irwan. "Analisis Terhadap Wewenang Notaris Dalam Membuat Surat Keterangan Waris Setelah Berlakunya Undang-Undang Nomor 30 Tahun 2004 Tentang Jabatan Notaris (Studi Terhadap Notaris di Kota Semarang)", Tesis, Program Pasca Sarjana Universitas Diponegoro Semarang 2005.

Damis, Harijah. Memahami Pembagian Warisan Secara Damai. Jakarta: MT.Al-Itqon. 2012.

Djakfar, Idris dan Taufik Yahya. Kompilasi Hukum Kewarisan. Jakarta: PT. Dunia Pustaka Jaya. 1995.

Ghofur Anshori, Abdul. Lembaga Kenotariatan Indonesia. Yogyakarta: UII Press. 2009.

Hatta, Ahmad. Tafsir Qur'an Perkata: Dilengkapi Dengan Asbabun Nuzul \& Terjemah. Jakarta: Maghfirah Pustaka. 2011.

Ihsan, A.Ghazali. Kaidah-Kaidah Hukum Islam. Semarang: Basscom Multimedia Grafika. 2015.

Iriandini Manik,Mia. "Analisis Yuridis Akta Keterangan Waris Yang Dibuat Oleh Notaris Dalam Ketentuan Pembuatan Akta Otentik Berdasarkan Uujn No. 2 Tahun 2014",Tesis Fakultas Hukum Universitas Sumatera Utara Medan 2014.

Lidwa Pusaka i-Software - Kitab 9 Imam Hadis HR. Bukhari No. 2542.

Lubis, Suhrawardi K. dan Komis Simanjuntak. Hukum Waris Islam. Jakarta: Sinar Grafika. 2008.

Mahali, A. Mudjab. Asbabun Nuzul: Studi Pendalaman Al-Qur'an Surat Al-Baqarah-AnNash. Jakarta: PT. Raja Grafindo Persada. 2002.

Mertokusumo, Sudikno. Hukum Acara Perdata di Indonesia, Yogyakarta: Liberty. 1981.

Muhibbin, Moh., Abdul Wahid. Hukum Kewarisan Islam Sebagai Pembaharuan Hukum Positif di Indonesia. Jakarta: Sinar Grafika. 2019.

Mustari, Abdillah. Hukum Kewarisan Islam. Makassar: Alauddin Press. 2013.

Nasution, Amin Husein. Hukum Kewarisan. Jakarta: Raja Grafindo Persada. 2012.
Perangin, Effendi. Hukum Waris. Jakarta: Rajawali Pers. 2008.

Purbenazir, Eka Rahayu. "Implementasi Hukum Waris Islam Pada Masyarakat Kecamatan Kepahiang Kabupaten Kepahiang", Jurnal Qiyas, Pascasarjana IAIN Bengkulu, Vol. 2, No. 1, April 2017.

Ramulyo, M. Idris. Perbandingan Hukum Kewarisan Islam dengan Kewarisan Kitab Undang-undang Hukum Perdata. Jakarta: Sinar Grafika. 2004.

Rofiq, Ahmad. Fiqh Mawaris. Jakarta Utara: PT Raja Grafindo Persada. 2015.

Rokhmad, Abu. Ushul Al- Fiqh, Semarang: CV. Karya Abadi, 2015.

Ruhani, Rosita. "Analisis Akta Pembagian Warisan Yang Dibuat Di Hadapan Notaris Menurut Hukum Islam", Jurnal Repertorium, Vol. III, No. 2, Juli-Desember 2016.

Saebani, Beni Ahmad. Fiqih Mawaris. Bandung: Pustaka Setia. 2012.

Sanusi, Ahmad. Ushul Fiqh. Jakarta: Rajawali Pers. 2015.

Satria Effendi. Ushul Figh. Jakarta: Prenada Media Group. 2008.

Sugiyono. Metode Penelitian Kuantitatif, Kualitatif Dan R\&D. Bandung: Alfabeta. 2013.

Syarifuddin, Amir. Ushul Fiqh. Jakarta: Logos Wacana Ilmu. 2001.

Thong Kie, Tan. Studi Notariat, Serba-serbi Praktek Notaris. Jakarta: PT. Ichtiar Baru Van Hoeve. 2000.

Tim Penyusun Kamus Pusat Bahasa. Kamus Besar Bahasa Indonesia. Jakarta: Balai Pustaka. 2011.

Undang-undang Nomor 2 tahun 2014 perubahan Undang-Undang Nomor 30 Tahun 2004 Tentang Jabatan Notaris.

Usman, Suparman dan Yusuf Somawinata. Figh Mawaris: Hukum Kewarisan Islam. Jakarta: Gaya Media Pratama. 2007.

Zahari, Ahmad. Tiga Versi Hukum Kewarisan Islam: Syafi'i, Hazairin, dan KHI. Pontianak: Romeo Grafik. 2013. 